\title{
Treatment of irregular bleeding with oestradiol during long-term levonorgestrel- releasing intrauterine system (LNG-IUS) use
}

\author{
Oderkerk TJ ${ }^{*}$, van der Heijden PAHH ${ }^{1,4}$, Tibosch RMG ${ }^{2}$, Bui BN ${ }^{3}$, Geomini PMAJ' and Bongers MY ${ }^{1,4}$ \\ ${ }^{1}$ Máxima Medical Center Veldhoven, de Run 4600, 5504 DB Veldhoven, The Netherlands \\ ${ }^{2}$ GGD Den Bosch, Vogelstraat 2, 5212 VL's-Hertogenbosch, The Netherlands \\ ${ }^{3}$ University Medical Center Utrecht, Heidelberglaan 100, 3584 CX Utrecht, The Netherlands \\ ${ }^{4}$ Grow, Research School of Oncology and Developmental Biology Maastricht University Maastricht, P. Debyelaan 25, 6229 HX, The Netherlands
}

\begin{abstract}
Objectives: Up to $60 \%$ of women remove their levonorgestrel-releasing Intrauterine System (LNG-IUS) prematurely, mostly because of irregular bleeding disturbances up to six months after insertion. Assuming ongoing bleeding is due to atrophic bleeding of the endometrium, treatment with ooestrogen could be effective. No study in literature supports ooestrogen therapy for irregular bleeding in LNG-IUS users.

Study design: A prospective cohort study was conducted in two hospitals to evaluate the effect of oral ooestradiol (started six months after LNG-IUS insertion) on irregular bleeding days. The participating women received $2 \mathrm{mg}$ ooestradiol daily for six weeks. We observed the discontinuation rate, the occurrence of adverse events and side effects due to ooestradiol. Women completed questionnaires at baseline and three months after start of the treatment.

Results: Nineteen women were included. A median of 21 irregular bleeding days per month at baseline decreased to a median of five irregular bleeding days per month ( $p=0.003$ ) after the use of ooestradiol for six weeks. Three out of nineteen women had their LNG-IUS removed at three months follow-up because of persistent irregular bleeding. No adverse events were reported, however, $68 \%$ of the participants reported side effects.

Conclusion: In this study we observed a decrease in the number of irregular bleeding days in LNG-IUS users with ongoing irregular bleeding (>6 months after insertion), after administering oral ooestradiol for six weeks. We propose to conduct a larger prospective trial to evaluate ooestradiol as treatment option for irregular bleeding.
\end{abstract}

\section{Introduction}

An intrauterine device is one of the most common methods for contraception used by women (between 15-49 years) all over the world: in 2015 fourteen per cent used an intra uterine contraceptive device [1]. One of the most commonly used intrauterine devices is the levonorgestrel intrauterine System (LNG-IUS; Mirena ${ }^{\oplus}$, Bayer HealthCare, Pittsburgh, PA, USA), which initially releases 20 micrograms levonorgestrel intrauterine every 24 hours. In the following five years, this progesterone declines to a rate of fourteen micrograms per day, which is proven still clinically effective for contraception. The LNG-IUS is also approved as a treatment option for heavy menstrual bleeding [2]. However, one of the main reasons to remove the LNGIUS prematurely is irregular bleeding disturbance. The incidence of irregular bleeding decreases over the first six months of use [3]. In some cases, irregular bleeding may continue after six months or occurs de novo over time during LNG-IUS use. The guidelines of the National Institute for Health and Clinical Excellence (NICE) make healthcare professionals aware of the fact that up to $60 \%$ of women remove the LNG-IUS prematurely [3]. The Dutch general practitioners' guideline recommend treatment with oral ooestrogen in women with ongoing irregular bleeding more than six months after insertion of their LNGIUS [4]. However, in literature, not one study supports ooestrogen therapy for irregular bleeding in LNG-IUS users [5]. Because of the physiological effect of levonorgestrel in downregulation of ooestrogen receptors in the endometrium resulting in endometrial atrophy, we hypothesize that the addition of ooestradiol might be beneficial for regeneration of the endometrium and consequently decreasing irregular bleeding [6,7].

In this prospective cohort study, we evaluate the effect of oral oestradiol on ongoing irregular bleeding disturbances during LNGIUS use more than six months after insertion.

\section{Material and methods}

This multicentre prospective cohort study was conducted between May 2017 and January 2018 in two teaching hospitals in the Netherlands.

${ }^{*}$ Correspondence to: Tamara Johanna Oderkerk, Department of Obstetrics and Gynaecology, Máxima Medical Center Veldhoven, de Run 4600, 5504 DB Veldhoven, The Netherlands, Tel: +31 40888 8380; Fax +31 40888 9564; E-mail: tamara.oderkerk@mm.cnl

Key words: levonorgestrel intrauterine system, LNG-IUS, irregular bleeding, ooestradiol

Received: September 06, 2019; Accepted: September 17, 2019; Published: September 23, 2019 
Women with an LNG-IUS in situ for more than six months, who visited the outpatient clinic with ongoing or de novo irregular bleeding disturbances were included. Exclusion criteria were women younger than 18 years, malposition of the LNG-IUS, known abnormal cervical cytology or (pre-) malignancies of the uterus, the presence of polyps, myomas on ultrasound or a contra-indication for oestradiol (history of thrombosis or mamma carcinoma). The study was registered in the Dutch trial register as NL8007. The ethics committee of the hospital approved the study on 12 May 2017 (N17.070). Written informed consent was obtained from all patients.

Patient characteristics including age, BMI, parity, indication for the LNG-IUS, bleeding pattern, the number of bleeding days, satisfaction with the bleeding pattern and previous therapies for the current complaints were collected at baseline.

Menstrual blood loss was assessed using a menstrual bleeding chart. The definitions used in this chart are described in table 1 [8]. Transvaginal ultrasound was performed to collect data about the endometrial thickness, the position of the LNG-IUS and to check for intrauterine abnormalities. All women used $2 \mathrm{mg}$ oestradiol orally once a day for six weeks. Questionnaires were completed at baseline and three months after start of treatment including a menstrual bleeding chart. The questionnaires included the following themes: therapy compliance, the bleeding pattern, number of bleeding days, satisfaction with the bleeding pattern (on a five-point Likert scale), satisfaction with the treatment, side effect of the treatment and adverse events. Additionally, patients were asked whether the LNG-IUS was removed. Data were collected in a Statistical Package for the Social Sciences-database, in which individual study numbers were assigned to every patient, ensuring patient anonymity. The categorical data were expressed as numbers and percentages. Continuous data with normal distribution were expressed as mean \pm standard deviation, while abnormal distributed continuous data were expressed as median and interquartile ranges. Wilcoxon signed rank test was used to compare continuous variables. A P-value $<0.05$ was considered statistically significant.

\section{Results}

A total of 25 women were included initially, one woman did not start with oestradiol after reading the warning on adverse effects as described in the leaflet of the oestradiol. Five women were lost to follow up despite to frequent recalls. In total nineteen women completed the follow-up period of three months and were used for analysis. Baseline characteristics are shown in table 2 . The mean age was $30.2( \pm 8.5)$ years. Most women initiated the LNG-IUS for contraception (57.9\%).

Fourteen out of the 19 patients used oestradiol $2 \mathrm{mg}$ for six weeks as prescribed (range 28-90 days). One patient used the oestradiol for four weeks because she was already satisfied with her menstruation pattern, and four patients used the oestradiol for a longer time up to 90 days. The total number of bleeding days decreased after treatment with oestradiol (Table 3). The baseline median of 21 (IQR 16.0-30.0) irregular bleeding days per month decreased to a median of 5 (IQR 3.0-11.0) irregular bleeding days per month ( $\mathrm{p}=0.003$ ). Before treatment with oestradiol, $68 \%$ of the woman reported spotting in their menstruation pattern, which decreased to $32 \%$ of the woman after treatment with oestradiol. Furthermore, $42 \%$ of the women reported normal menstruation after treatment with oestradiol.

Three women $(15,8 \%)$ removed their LNG-IUS prematurely during the follow-up period, two women because of persisting irregular bleeding and one woman because of abdominal pain. No adverse effects were reported. Side-effects were reported by $68,4 \%$ of women. Most reported side-effects included painful swollen breasts $(26 \%)$, mood swings (21\%), headache (16\%), weight gain (16\%) and vaginal complaints (11\%).

13 of the $19(68,4 \%)$ women are more satisfied on a five-point Likert scale after the treatment with oestradiol with their bleeding pattern (Figure 1). $29 \%$ of women were (very) unsatisfied, $28 \%$ or the

Table 1. Definition of the menstrual bleeding chart [8].

\begin{tabular}{|l|l|}
\hline Normal menstruation & Cycle of 24-38 days, menstrual period 4, 5-8 days \\
\hline $\begin{array}{l}\text { Heavy menstrual } \\
\text { bleeding }\end{array}$ & $\begin{array}{l}\text { Regular cycle, severe and/or prolonged blood loss }(\geq 2 \text { days of } \\
\text { clots and/or menstrual duration }>8 \text { days) }\end{array}$ \\
\hline Metrorrhagia & $\begin{array}{l}\text { Unrecognizable cycle, varying amounts } \\
\text { and intervals (time between two bleeding }<20 \text { days) }\end{array}$ \\
\hline $\begin{array}{l}\text { Intermenstrual } \\
\text { bleeding }\end{array}$ & Normal menstruation with intermenstrual bleeding. \\
\hline Contact bleeding & Blood loss as a result of coitus \\
\hline $\begin{array}{l}\text { Spotting with } \\
\text { hormonal therapy }\end{array}$ & $\begin{array}{l}\text { Slight blood loss between (or without) the withdrawal bleeding } \\
\text { or natural periods. }\end{array}$ \\
\hline $\begin{array}{l}\text { Blood loss } \\
\text { corresponding a } \\
\text { section-niche }\end{array}$ & $\begin{array}{l}>2 \text { days of brown discharge at the end of the menstruation } \\
\text { (duration }>8 \text { days) or intermenstrual bleeding that starts within } 5 \\
\text { days after menstruation. }\end{array}$ \\
\hline
\end{tabular}

Table 2. Baseline characteristics. *2 missing; a: Data are given as mean \pm standard deviation.

\begin{tabular}{|l|l|}
\hline Characteristics & $\mathbf{N}=\mathbf{1 9}$ \\
\hline Maternal age, $\mathrm{y}^{\mathrm{a}}$ & $30.2( \pm 8.7)$ \\
\hline Body Mass Index $\mathrm{kg}^{\mathrm{m}} \mathrm{m}^{2 \mathrm{a}}$ & $23.4( \pm 3.0)$ \\
\hline Parity, $\mathrm{n}(\%)$ & $10(52.6)$ \\
\hline Nulliparity & $9(47.4)$ \\
\hline Multiparity & $11(57.9)$ \\
\hline Indication of LNG-IUS, $\mathrm{n}(\%)$ & $5(26.3)$ \\
\hline Contraception & $2(10.5)$ \\
\hline Heavy menstrual bleeding & $1(5.3)$ \\
\hline Contraception and heavy menstrual bleeding & \\
\hline Spotting during use of OAC & $6(31.6)$ \\
\hline Satisfaction bleeding pattern, $\mathrm{n}(\%)$ & $11(57.9)$ \\
\hline 1 very unsatisfied & $1(5.3)$ \\
\hline 2 unsatisfied & 0 \\
\hline 3 neutral & $1(5.3)$ \\
\hline 4 satisfied & \\
\hline 5 very satisfied & $13(68.4)$ \\
\hline Previous treatment, $\mathrm{n}(\%)$ & $6(31.6)$ \\
\hline No & \\
\hline Yes, lynestrenol & \\
\hline
\end{tabular}

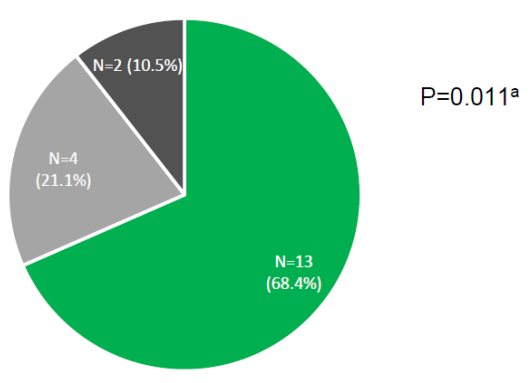

- Improved =Equal - Deteriorated

a. Wilcoxon signed rank test

Figure 1. Satisfaction blood loss before and after treatment with oestradiol 
Table 3. At 3-month follow-up. a: Data are given as median (Interquartile Range), b: Wilcoxon signed rank test

\begin{tabular}{|l|l|l|l|}
\hline & $\begin{array}{l}\text { Before oestradiol } \\
\text { treatment (N=15) }\end{array}$ & $\begin{array}{l}\text { After oestradiol } \\
\text { treatment (N=16) }\end{array}$ & P value \\
\hline $\begin{array}{l}\text { Number of bleeding } \\
\text { days }^{\mathbf{a}}\end{array}$ & $21.0(16.0-30.0)$ & $5.0(3.0-11.0)$ & $0.003^{\mathrm{b}}$ \\
\hline Menstrual pattern (\%) $^{\mathbf{2}}$ & & & \\
\hline No menstruation & $0(0)$ & $1(0.5)$ & \\
\hline Normal menstruation & $0(0)$ & $8(42)$ & \\
\hline $\begin{array}{l}\text { Heavy menstrual bleeding } \\
\text { Metrorrhagia }\end{array}$ & $2(11)$ & $0(0)$ & \\
\hline Intermenstrual bleeding & $2(11)$ & $3(16)$ & \\
\hline Contact bleeding & $3(16)$ & $5(26)$ & \\
\hline Spotting & $2(11)$ & $2(11)$ & \\
\hline Blood loss corresponding & $13(68)$ & $6(32)$ & \\
\hline section-niche & $0(0)$ & $0(0)$ & \\
\hline
\end{tabular}

women scored neutral and $45 \%$ of the women were (very) satisfied with the oestradiol treatment.

\section{Discussion and conclusion}

In this feasibility study, a reduction in the number of bleeding days during long term LNG-IUS use was found after treatment with oestradiol for six weeks. No adverse effects were reported, but several side-effects were reported (i.e. mood swings and swollen breasts). This suggests that oestradiol might be an effective treatment for ongoing irregular bleeding disturbances in long-term LNG-IUS users. Hypothetically, the irregular bleeding is caused by the progesteroneonly treatment in the LNG-IUS. Progesterone causes an increase of fragile superficial vessels of the endometrium. These vessels tear down easily, resulting in a breakthrough bleeding [9]. The progesterone in the uterus has a mechanism of downregulating oestrogen receptors in the stroma cells in the basal layer of the endometrium, which leads to endometrial atrophy [6] By addition of oral oestrogen, an up-regulation of oestrogen receptors will take place, which might have a positive effect on irregular bleeding. Evidence for above hypothesis is lacking. After systematic search in literature we did not find publications on treatment for ongoing or the novo irregular bleeding disturbances more than six months after LNG-IUS insertion [10-13]. We found four studies describing prophylactic treatment regimens, starting straight treatment after LNG-IUS insertion.

One of the studies evaluated the prophylactic effect of oestradiol on irregular bleeding after insertion of the LNG-IUS [7]. However, a disadvantageous effect of oestradiol patches was shown. We hypothesize that there is a different mechanism of irregular bleeding disturbances in short-term use compared to long-term use. Probably the atrophic endometrium bleeding occurs later on and oestrogen treatment straight after insertion results in a contra effective effect. Although adverse events did not occur, most women in this study experienced side- effects from the oestradiol tablets. Frequent reported side-effects were reported painful swollen breasts, mood swings, headache and weight gain. This is important to include in counselling future patients. Regardless of the reported side-effects, most women stayed neutral or were (very) satisfied with the treatment. Results of this study support the hypothesis that ongoing bleeding is due to atrophy of the endometrium and form the basis to perform future research. The strong feature of this study is that it shows the first results of a treatment in long- term LNG-IUS users with irregular bleeding disturbances.

The present study has also some limitations. The sample size of this prospective, non-randomized cohort study is small $(n=19)$. Hence, selection bias could be introduced which may limit our generalizability and limits also the ability for statistical analysis. There is also the risk of recall bias as women were asked for number of bleeding days in the last months (prior to starting oestradiol treatment). Finally, follow up was limited to three months. Long term follow-up is needed in future studies.

In conclusion, oestradiol may be a promising and safe treatment for irregular bleeding disturbances in long-term LNG-IUS users. First, we will start a large prospective study followed by a placebo-controlled trial evaluating addition of oestradiol as the treatment for irregular bleeding disturbances during long term LNG-IUS use.

\section{Implications for practice and/or policy}

Results of this feasibility study form the basis to perform future research.

\section{References}

1. United Nations, Department of Economic and Social Affairs, Population Division (2015) Trends in Contraceptive Use Worldwide 2015 (ST/ESA/SER.A/349). Available from: https://www.un.org/en/development/desa/population/publications/pdf/family/ trendsContraceptiveUse2015Report.pdf

2. Ewies AA (2009) Levonorgestrel-releasing Intrauterine System - The discontinuing story. Gynecol Endocrinol 25: 668-673. [Crossref]

3. National-Institute-for-Health-and-Clinical-Excellence (2005) Long- acting reversible contraception. NICE Clinical Guidelines 30. London: RCOG. Available from: https:// www.rcog.org.uk/en/guidelines-research-services/guidelines/long-acting-reversiblecontraception-update-nice-clinical-guideline-30/

4. Meijer LJ, Bruinsma ACA, Pameijer AS, Hehenkamp WJK, Janssen CAH, et al. (2014) NHG-Standaard Vaginaal bloedverlies (derde herziening). Huisarts Wet 57: 406-414.

5. Abdel-Aleem H, d'Arcangues C, Vogelsong KM, Gaffield ML, Gulmezoglu AM (2013) Treatment of vaginal bleeding irregularities induced by progestin only contraceptives. Cochrane Database Syst Rev 18: CD003449. [Crossref]

6. Critchley HO, Wang H, Kelly RW, Gebbie AE, Glasier AF (1998) Progestin receptor isoforms and prostaglandin dehydrogenase in the endometrium of women using a levonorgestrel-releasing intrauterine system. Hum Reprod 13: 1210-1217. [Crossref]

7. Nilsson CG, Lähteenmäki PL, Luukkainen T (1984) Ovarian function in amenorrheic and menstruating users of a levonorgestrelreleasing intrauterine System. Fertil Steril 41: 52-55. [Crossref]

8. Maarse M, Bij de Vaate AJM, Huirne JAF, Brölman HAM (2011) The monthly calendar, a tool for an efficient menstrual history. Dutch J Obstet Gynecol 124: 231-236.

9. Hickey M, d'Arcangues C (2002) Vaginal bleeding disturbances and implantable contraceptives. Contraception 65: 75-84. [Crossref]

10. Warner P, Guttinger A, Glasier AF, Lee RJ, Nickerson S, et al. (2010) Randomized placebo-controlled trial of CDB-2914 in new users of a levonorgestrel-releasing intrauterine system shows only short-lived amelioration of unscheduled bleeding. Hum Reprod 25: 345-353. [Crossref]

11. Madden T, Proehl S, Allsworth JE, Secura GM, Peipert JF (2012) Naproxen or estradiol for bleeding and spotting with the levonorgestrel intrauterine system: a randomized controlled trial. American Am J Obstet Gynecol 206: 129.e1-e8. [Crossref]

12. Sørdal T, Inki P, Draeby J, O'Flynn M, Schmelter T (2013) Management of initia bleeding or spotting after levonorgestrel-releasing intrauterine system placement: a randomized controlled trial. Obstet Gynecol 121: 934-941. [Crossref]

13. Lal S, Kriplani A, Kulshrestha V, Sharma M, Agarwal N (2010) Efficacy of mifepristone in reducing intermenstrual vaginal bleeding in users of the levonorgestrel intrauterine system. Int J Gynecol Obstet 109: 128-130. [Crossref]

Copyright: (C2019 Oderkerk TJ. This is an open-access article distributed under the terms of the Creative Commons Attribution License, which permits unrestricted use, distribution, and reproduction in any medium, provided the original author and source are credited. 